\title{
Prevalence of microscopic fungi in bee pollen
}

\section{Jolanta Sinkevičien $\dot{e}^{\star}$,}

\author{
Algirdas Amšiejus \\ Institute of Biology \\ and Plant Biotechnology, \\ Agricultural Academy \\ of Vytautas Magnus University, \\ 11 Studentu St., Akademija 53361, \\ Kaunas district, Lithuania
}

\begin{abstract}
One of the problems with storing bee products - pollen - is their microbiological pollution. With high levels of pollen contamination by microscopic fungi, toxins synthesized by the fungi of some genera can have a negative impact on human health. During the experiment, the prevalence of microscopic fungi in pollen was evaluated, and their genera and species were identified. Pollen samples were collected at different times of the year - spring and summer - in order to ascertain the abundance and diversity of different fungal genera and species. The dilution method $(\mathrm{CFU} / \mathrm{g})$ was used to determine the number of fungal strains per sample and their amount. The total number of fungal strains in the pollen collected in spring ranged from 1.3 to $5.7 \times 10^{-3} \mathrm{CFU} / \mathrm{g}$, in summer -1.0 to $5.8 \times 10^{-3} \mathrm{CFU} / \mathrm{g}$. In the pollen, 11 genera and six species of fungi were identified. The number of fungal genera and species in pollen collected in spring and summer varied insignificantly. In spring, ten genera and six species of fungi were isolated from pollen, and in summer 11 genera and six species were identified. Penicillium and Alternaria fungi dominated the bee pollen.
\end{abstract}

Keywords: bee pollen, fungi, moulds, contamination

\section{INTRODUCTION}

Plant pollen collected by bees is considered one of the most complete food items in nature (Petrovic et al., 2014). According to the structural components of pollen, there is no other product that could substitute them (Gendrolis, 2012). Pollen contains about 200 different substances (including proteins, carbohydrates, flavonoids, enzymes, trace elements, abundant amino acids and vitamins (Deveza et al., 2015; Kieliszek et al., 2018)). Bee pollen is delivered as a healthy food supplement and a dietary product (Hassan, 2011).

\footnotetext{
*Corresponding author. Email: jolanta.sinkeviciene@vdu.lt
}

An important criterion of the standard of pollen quality is microbiological contamination. The quality of pollen collected by bees is highly dependent on environmental factors that affect the activity of microscopic fungi and bacteria (Xue et al., 2014). Microscopic fungi, which are always abundant in the environment, begin to develop as soon as favourable humidity and temperature conditions are formed. They are capable of growing at a temperature of $10-40^{\circ} \mathrm{C}$ when water activity $\left(a_{w}\right)$ ranges from 0.62 to 1 (Petrovic et al., 2014). Fresh pollen collected by bees has high humidity level because it is highly hygroscopic. Under favourable conditions, pollen may become a rich medium for the multiplication of microorganisms that utilize amino acids of pollen as the main source of carbon for energy 
production during their growth (DeGrandiHoffman et al., 2013).

Microscopic fungi are a very diverse, viable, and active group of microorganisms that are capable of active synthes and release of toxic metabolites of various chemical nature into the environment (Lugauskas, 2006). There is a growing concern about contamination of food by mycotoxins, and pollen is not an exception. Mycotoxins are secondary metabolites produced by a number of fungal species: Fusarium, Aspergillus, Alternaria and Penicillium (Akond et al., 2012). Each type of fungi is characterized by its specific metabolites, the intensity of synthesizing of which is determined by the nature of the individual, and the environment in which the processes of toxin synthesis take place (Lugauskas, 2006). The cause of the occurrence of mycotoxins depends on such factors as humidity, temperature, storage time, level of contamination, presence of impurities, and transport (Birck et al., 2006). Since the mycotoxins formed cannot be eliminated, it is very important to avoid food contamination with mold (Gompa, 2013).

Microscopic fungi under natural conditions are very difficult to control (Finola et al., 2007). They are very widespread in nature and have different spores resistant to various environmental influences that pollute not only pollen, but can also enter honey together with the pollen (Popa et al., 2009). Therefore, it is very important to find out which species of fungi predominate in pollen, because some fungi are potential mycotoxin producers, while others, although not producing toxic metabolites, can cause allergic reactions (Estevinho et al., 2011). Often the impact of fungi on the environment is negative. Therefore, in order to achieve a balance beneficial to humans in nature, their activity needs to be limited, regulated, and directed towards being useful (Lugauskas et al., 2002).

The aim of the research was to investigate the occurrence of microscopic fungi at different times of the year in pollen collected by bees and to identify the genera and species of the fungi.

\section{MATERIALS AND METHODS}

In the study, 46 pollen samples collected in spring and summer from the same apiary families were investigated. Spring pollen was collected in the third decade of May, and summer pollen in the third decade of August. The collected pollen samples (50 g) were placed in sterile plastic bags. The pollen, dried down to $8.0 \%$ humidity, was stored in the freezer at $-15^{\circ} \mathrm{C}$ until the mycological analysis.

The dilution method (CFU/g) was used to determine the number and amount of fungi on the surface and inside the sample (LST ISO 6611: 2004). Microscopic fungi were isolated by adding $10 \mathrm{~g}$ of ground pollen to $90 \mathrm{ml}$ of physiological saline $(\mathrm{NaCl}, 8.5 \mathrm{~g} / \mathrm{l})$ and shaking in a shaker for $15 \mathrm{~min}$ (at $400 \mathrm{rpm}$ ). A series of dilutions were prepared from the resulting suspension. One millilitre of $10^{-2}, 10^{-3}$, and $10^{-4}$ suspensions were dispensed in Petri dishes ( $8 \mathrm{~cm}$ diameter) on which the Potato Dextrose Agar (PDA) medium was infused. For extracting the yeast, $0.1 \mathrm{ml}$ of $10^{-1}, 10^{-2}$, and $10^{-3}$ suspensions were spread in Petri dishes over a suspended Sabur Dextrose Agar (SDA) medium and dispersed with a Drigalski lens.

All cultures were performed in triplicate. Petri dishes with cultures were maintained for 5-7 days in a thermostat at $26 \pm 2^{\circ} \mathrm{C}$, and for the isolation of yeast the plates with cultures were maintained for 2-4 days. The grown fungi were counted and evaluated as colony-forming units per gram of bee pollen (CFU/g). Morphological features of the colonies of the raised fungi were evaluated macroscopically (colony occurrence) and examined by light microscopy. Separate fungal colonies were purified to monocultures and identified by cultural and morphological features based on various descriptors (Domsch et al., 1980; Ellis, 1971; 1976; Gerlach et al., 1982; Nelson et al., 1983).

The number of colony-forming units (CFU) per $1 \mathrm{~g}$ of product were determined as follows: $N=\Sigma C /\left(n_{1}+0.1 n_{2}\right) x d$, where: $\Sigma C-$ the amount of colonies counted on all plates selected for evaluation; $n_{1}$ - number of the first dilution plates with 10 to 300 colonies counted; 
$n_{2}$ - number of the second dilution plates with 10 to 300 colonies counted; $d$ - the dilution factor corresponding to the first dilution, the plates of which were selected for colony counting (LST ISO 6611: 2004).

\section{RESULTS AND DISCUSSION}

In spring and summer, nine genera of microscopic fungi of the mitochondrial fungi ( $\mathrm{Deu}$ teromycota, Hyphomycetes class) prevailed in the pollen collected by bees: Acremonium, Alternaria, Aspergillus, Botrytis, Cladosporium, Fusarium, Mucor, Penicillium, Mycelia sterilia. Among the identified fungi, at one of the identified genera belonged to the classes of Zygomycetes (Mucor, Rhizopus spp.) and Ascomycetes (yeast) (Table 1).

During the study, the dependence of pollen contamination by fungi at the time of its collection (spring, summer) was determined. The total number of microscopic fungal strains in the pollen collected in spring and summer was similar, ranging from 1.3 to 5.7 and 1.0 to $5.8 \times 10^{-3} \mathrm{CFU} / \mathrm{g}^{-1}$, respectively (Table 1 ). Fresh pollen collected by bees contains a lot of moisture (Gendrolis, 2012), and the amount of microscopic fungi in the substrate is dependent on its amount (Logrieco, 2004). According to research carried out in Lithuania (Virketis, 1993), the greatest amount of moisture in freshly collected pollen was found in summer, and it was the driest in autumn.

In the collected spring pollen, ten genera and six species were isolated, and fungi belonging to 11 genera and six species were identified at the end of summer. Penicillium (33.33\%), Alternaria (18.18\%), Mucor (15.15\%) and Aspergillus $(10.03 \%)$ genera prevailed in the pollen collected in spring, while the summer pollen was dominated by Alternaria (38.89\%), Penicillium (21.88\%), Mucor (12.5\%), and Cladosporium (12.5\%). The amounts of Acremonium, Botrytis, and Fusarium fungi were the lowest in different seasonal samples.

In the spring samples of pollen, the most frequently occurring was the Penicillium genus $-33.33 \%$. Contamination of pollen samples by this genus amounted to $5.7 \times 10^{-3} \mathrm{CFU} / \mathrm{g}$ and was the highest in comparison to other identified fungal genera. Studies by Gonzales et al., 2005; Finola et al., 2007, showed that the fungi of the genus Penicillium were predominant in pollen. The Penicillium genus was not so abundant in the pollen collected in the summer: its occurrence amounted to $21.88 \%$, which comprised $4.5 \times 10^{-3} \mathrm{CFU} / \mathrm{g}$. Penicillium spp. is found wherever organic material is available.

Table 1. The levels of fungal contamination of bee pollen (CFU/g)

\begin{tabular}{c|cc}
\hline \multirow{2}{*}{ Fungi } & \multicolumn{2}{|c}{ Fungal contamination $\left(\mathrm{CFU} / \mathrm{g}^{-1}\right)$} \\
\cline { 2 - 3 } & Spring pollen & Summer pollen \\
\hline Acremonium spp. & $1.3 \times 10^{4}$ & $1.2 \times 10^{4}$ \\
\hline Alternaria spp. & $3 \times 10^{3}$ & $5.8 \times 10^{3}$ \\
\hline Aspergillus spp. & $1.9 \times 10^{3}$ & $2.0 \times 10^{3}$ \\
\hline Botrytis spp. & $1.3 \times 10^{4}$ & $1.0 \times 10^{3}$ \\
\hline Cladosporium spp. & $1.6 \times 10^{4}$ & $2.5 \times 10^{4}$ \\
\hline Fusarium spp. & $1.6 \times 10^{3}$ & $1.4 \times 10^{3}$ \\
\hline Mucor spp. & $2.7 \times 10^{3}$ & $2.5 \times 10^{3}$ \\
\hline Penicillium spp. & $5.7 \times 10^{3}$ & $4.5 \times 10^{3}$ \\
\hline Rhizopus spp. & - & $1.0 \times 10^{3}$ \\
\hline Yeast & $2.3 \times 10^{3}$ & $1.5 \times 10^{3}$ \\
\hline Mycelia sterilia & $1.0 \times 10^{3}$ & $1.4 \times 10^{3}$ \\
\hline
\end{tabular}

${ }^{\star} \mathrm{Cfu} / \mathrm{g}^{-1}-$ colony forming units per gram of bee pollen 
It was found that this genus is most commonly detected in honey (Kačaniova, 2007). Low $a_{w}$ may explain the frequent occurrence of this fungus in pollen (Gonzalez, 2005).

Penicillium verrucosum is a species of the Penicillium genus that is most frequently found in spring pollen (Table 2). This species was found in $27.27 \%$ of pollen samples examined. However, this species was not characterized by the most frequent occurrence in the pollen collected in summer. P. verrucosum was isolated in $16.78 \%$ of pollen and was the third most abundant fungus. Penicillium isolates in food raw materials should be considered as potential mycotoxin producers (Leistner, 1984). Considering the potential mycotoxin producing species, $P$. verrucosum is one of those producing ochratoxin A, which has carcinogenic, teratogenic, and immunosuppressive properties. Ochratoxin also has an effect on the immune system, reproductive function, and the activity of genes (Bucheli, Taniwaki, 2002).

Studies have shown that the fungi of the Aspergillus genus in the pollen collected in spring and summer were not abundant. They were identified in $10.03 \%$ of spring and in $10.10 \%$ of summer pollen samples.

Aspergillus flavus was found in $9.09 \%$ of spring pollen, and in $8.02 \%$ of summer samples. The species of the Aspergillus genus - A. fumigantus and A. flavus - produce aflatoxins, which are among the most harmful mycotoxins. They are toxic, carcinogenic, and mutagenic (Bennett, 2010; Krnjaja et al., 2013). Examination of pollen samples collected in summer showed that contamination by $A$. niger fungus comprised $1.0 \%$. Apart from aflatoxin, A. niger can also produce fumonisin $\mathrm{B}_{2}$. Fumonisins cause toxicosis and are considered carcinogens (Mogensen et al., 2010).

Fusarium fungi in the examined pollen samples were not dominant. The number of fungal strains in the collected spring pollen samples comprised $9.09 \%\left(1.6 \times 10^{-3} \mathrm{CFU} / \mathrm{g}\right)$, and in summer samples $8.91 \%\left(1.4 \times 10^{-3} \mathrm{CFU} / \mathrm{g}\right)$. Favourable conditions for Fusarium spp. occurrence require a substrate containing about $60 \%$ of the available water (Llorens et al., 2004), possibly influencing the spread of this fungus in the dried pollen. In the study, two most common Fusarium spp. species - F. graminearum (5.18\%) and F. sporotrichioides (2.09\%) were identified. Toxic fungi are divided into field and storage fungi. Fusarium is the main genus of the field fungi which produce toxins, while Aspergillus and Penicillium spp. belong to the storage fungi (Logrieco, 2004). The occurrence of Fusarium spp. was not as pronounced as in the studies conducted in 2016 by Nardoni et al. Unlike Aspergillus and Penicillium, whose occurrence requires attention in all stages of pollen storage and processing, Fusarium spp. is not significant at these stages (Nardoni, 2016). However, improper drying and prolonged storage of pollen may provide favourable conditions for the growth of Fusarium spp. and the biosynthesis of mycotoxins. Rodríguez-Carrasco, 2013, isolated Fusarium spp. mycotoxins from improperly dried pollen.

Table 2. The occurrence of fungi on bee pollen

\begin{tabular}{|c|c|c|}
\hline \multirow{2}{*}{ Fungi } & \multicolumn{2}{|c|}{ Occurrence, $\%$} \\
\hline & Spring pollen & Summer pollen \\
\hline Alternaria alternata (Fr.) Keissl. & 10.18 & 20.81 \\
\hline Aspergillus flavus Link. & 9.09 & 8.02 \\
\hline Aspergillus niger Tiegh. & - & 1.0 \\
\hline Cladosporium cladosporioides (Fresen.) G. A. de Vries & 6.18 & 22.22 \\
\hline Fusarium sporotrichioides Sherb. & 2.09 & 4.08 \\
\hline Fusarium graminearum Schwabe & 5.18 & - \\
\hline Penicillium verrucosum Dierckx & 27.27 & 16.78 \\
\hline
\end{tabular}


In the pollen samples collected in the spring of 2008, Alternaria spp. comprised $18.18 \%$, whereas in summer pollen its prevalence was relatively high: it was the most frequently identified genus with an occurrence of $38.89 \%$. The representative of this genus A. alternata had a prevalence of $20.81 \%$ in pollen samples, which was by $10.63 \%$ higher than in the spring samples. Alternaria alternata, one of the most commonly encountered in the Alternaria genus, is the one which most abundantly produces mycotoxin alternariol (Kononenko et al., 2015). In 2011, Kačaniova found that Alternaria sp., Mycelia sterilia and Aspergillus candidus are often found in honey, with an occurrence of $1.0 \times 10^{2} \mathrm{CFU} / \mathrm{g}^{-1}$ to $4.50 \times 10^{3} \mathrm{CFU} / \mathrm{g}^{-1}$.

A higher amount of yeast was detected in spring than in summer pollen. Although some authors (De-Melo et al., 2015) find their amounts ranging from $96.6 \%$ to $57.7 \%$, others (Nardoni et al., 2016) failed to detect any isolates in the examined specimens.

Fungi of other genera (Acremonium, Mucor Cladosporium) were not extensively abundant. Almost all of the samples examined had fungi of the Mucor genus. This is one of the most common fungal genera in both spring and summer samples, with isolates of $2.7 \times 10^{3}$ and $2.5 \times 10^{3} \mathrm{CFU} / \mathrm{g}^{-1}$, respectively. The occurrence of Acremonium genera in the pollen was insignificant. Pollen collected at the end of summer contained a higher amount of Cladosporium spp. as compared to spring pollen. Cladosporium fungi are present in the environment on substrates of various chemical composition, their spores are often found in humid air (Deveza et al., 2015). In the studies, C. cladosporioides was one of the most frequently isolated micromycetes in pollen collected at the end of summer.

Storage conditions are very important for the quality standards of pollen (Kačaniova, 2012). Humidity and temperature are the main factors that determine the occurrence and the amount of microscopic fungi in this bee product. In freshly collected pollen, humidity ranges from $20 \%$ to $30 \%$ (Bogdanov, 2004), in dried ones from 2\% to 9\% (Gonzalez et al., 2005). The humidity of improperly dried or unsuitably stored pollen promotes fungal activity (Bobis et al., 2010).

\section{CONCLUSIONS}

In this study, the majority of isolates were classified as saprotrophs that are capable of growing on different substrates under favourable conditions. Due to the contained nutrients, pollen is a particularly good substrate for microorganisms. Studies have shown that pollen collected in different seasons was equally abundantly contaminated by microscopic fungi. The amount of fungi and the structure of the genera isolated from pollen showed that they included the genera Penicillium, Alternaria, Fusarium, and Aspergillus that can produce toxins which can adversely affect the quality of this exceptional and curative product.

Studies by different authors have shown that contamination of pollen by microscopic fungi is unavoidable when storing it in the conditions of high relative humidity at room temperature. Therefore, in order to reduce the contamination of pollen by micro-organisms, it should be properly prepared for storage and stored in appropriate conditions.

Received 27 January 2019

Accepted 21 March 2019

\section{References}

1. Akond ASMG, Pounders MC, Blythe EK, Wang X. Longevity of crapemyrtle pollen stored at different temperatures. Sci Hort. 2012; 139: 53-7.

2. Bennet JW. An overview of the genus Aspergillus. In: Machida $\mathrm{M}$, Gomi $\mathrm{K}$, editor. Aspergillus: molecular biology and genomics. Norfolk: Caister Academic Press; 2010. p. 151-73.

3. Birck NMM, Lorini I, Scussel VM. Fungus and mycotoxins in wheat grain at post harvest. 
In 9th International Working Conference on Stored Product Protection. Campinas - Brazil. 2006; p. 198.

4. Bobis O, Marghitas LA, Dezmirean D, Morar O, Bonta V, Chirila AF. Quality parameters and nutritional value of different commercial bee products. Bulletin of University of agricultural sciences and veterinary medicina Ciaj-Napoca. J Anim Sci Biotechnol. 2010; 67: 1-2.

5. Bogdanov S. Quality and standard of pollen and beeswax. Apiacta. 2004; 38: 334-41.

6. Bucheli P, Taniwaki MH. Research on the orgin, and on the impact of post-harvest handling and manufacturing on the presence of ochratoxin A in coffee. Food Addit Contam. 2002; 19(7): 655-64.

7. DeGrandi-Hoffman G, Chen Y, Simonds R. The effects of pesticides on queen rearing and virus titers in honey bees (Apis mellifera L.). Insects. 2013; 4(1): 71-89.

8. De-Melo AA, Estevinho ML, Almeida-Muradian LB. A diagnosis of the microbiological quality of dehydrated bee-pollen produced in Brazil. Lett Appl Microbiol. 2015; 61: 477-83.

9. Deveza MV, Keller KM, Lorenzon MCA, Nunes IMT, Sales EO, Bart O. Mycotoxicological and palynological profiles of commercial brands of dried bee pollen. Braz $\mathrm{J}$ Microbiol. 2015; 46(4): 1171-6.

10. Domsch KH, Gams W, Anderson TH. Compendium of soil fungi. London: Academic Press; 1980. p. 860.

11. Ellis MB. Dematiaceous Hyphomycetes. Commonwealth Mycological Institute, Kew: Surrey; 1971. 608 p.

12. Ellis MB. Dematiaceous Hyphomycetes. Commonwealth Mycological Institute Kew: Surrey; $1976.507 \mathrm{p}$.

13. Estevinho ML, Afonso SE, Feas X. Antifungal effect of lavender honey against Candida albicans, Candida crusei and Cryptococcus neuformans. J Food Sci Technol. 2011; 48(5): 640-3.
14. Finola MS, Lasagno MC, Marioli JM. Microbiological and chemical characterization of honeys from central Argentina. Food Chem. 2007; 100(4): 1649-53.

15. Gendrolis A. Žiedadulkès ir bičių duonelè. Kaunas; 2012. 224 p. Lithuanian.

16. Gerlach W, Nirenberg H. The genus Fusarium - a pictorial atlas. Berlin; Hamburg; 1982. $409 \mathrm{p}$.

17. Gompa L. Ochratoxin A. Evaluation of methodologies for determination of ochratoxin A in food commodities, contamination levels in different products available in the US market and evaluation of fungal microbiota associated with some of the products [Master's dissertation]. Lincoln, Nebraska; 2013. $134 \mathrm{p}$.

18. González G, Hinojo MJ, Mateo R, Medina AM, Jiménez AM. Occurrence of mycotoxin producing fungi in bee pollen. Int J Food Microbiol. 2005; 105: 1-9.

19. Hassan HMM. Chemical Composition and Nutritional Value of Palm Pollen Grains. GJ BB. 2011; 6(1): 1-7.

20. Kačaniova M, Sudzina M, Sudzinova J, Fikselova M, Cubon J, Hascik P. Microbiological and physico-chemical quality of honey collected from different Slovak habitats. Slovak Journal of Animal Science. 2007; 40(1): 38-43.

21. Kieliszek M, Piwowarek K, Kot MA, Blažejak S, Chlebowska-Smigiel A, Wolska I. Pollen and bee bread as new healt - oriented products. Trends Food Sci Technol. 2018; 71: 170-80.

22. Kononenko GP, Burkin AA, Gavrilova OP, Gagkaeva TY. Fungal species and multiple mycotoxin contamination of cultivated grasses and legumes crops. Agr Food Sci. 2015; 24: $323-30$.

23. Krnjaja VS, Levic JT, Stankovic SŽ, Petrovic TS, Lukic MD. Molds and mycotoxins in freshly harvested maize. Proc Ant Sci. 2013; 124: 111-9. 
24. Leistner L. Toxinogenic penicillia occurring in feeds and foods: a review. Food Technol Austral. 1984; 36: 404-13.

25. Llorens A, Mateo R, Hinojo M, Jimenez M. Influence of environmental factors on the biosynthesis of type B trichothecenes by isolates of Fusarium spp. from Spanish crops. Int J Food Microbiol. 2004; 94: 43-54.

26. Logrieco A, Visconti A. An overview on toxigenic fungi and mycotoxins in Europe. 1st ed. Dordrecht: Kluwer Academic Publishers. 2004. 259 p.

27. Lugauskas A. Mikotoksinų kaupimosi maiste désningumai ir prevencinių saugos priemonių paieška. Maisto chemija ir technologija. 2006; 40(2): 16-27. Lithuanian.

28. Lugauskas A, Paškevičius A, Repečkienė J. Patogeniški ir toksiški mikroorganizmai žmogaus aplinkoje. Vilnius: Aldorija. 2002. p. 434. Lithuanian.

29. Mogensen JM, Frisvad JC, Thrane U, Nielsen KF. Production of fumonisin B2 and B4 by Aspergillus niger on grapes and raisins. J Agr Food Chem. 2010; 58: 954-8.

30. Nardoni S, D’Ascenzi C, Rocchigiani G, Moretti V, Mancianti F. Occurrence of moulds from bee pollen in Central Italy - a preliminary study. Ann Agric Environ Med. 2016; 23(1): 103-5.

31. Nelson PE, Tousson TA, Marasas WFO. Fusarium species. An illustrated manual for identification. University Park: Pennsylvania State University Press; 1983. p. 226.

32. Petrovic T, Nedic N, Paunovic D, Rajic J, Matovic K, Radulovic V, Krnjaja V. Natural mycobiota and aflatoxin B1 presence in bee pollen collected in Serbia. Biotechnol Anim Husb. 2014; 30(4): 731-41.

33. Popa M, Vica M, Axinte R, Glevitzky M, Varvara $\mathrm{S}$. Study concerning the honey qualities in Transylvania region. Ann Universe Apulensis Series Oecon. 2009; 11(2): 1034-40.

34. Rodríguez-Carrasco Y, Font G, Mañes J, Berrada $H$. Determination of mycotoxins in bee pollen by gas chromatography-tandem mass spectrometry. J Agr Food Chem. 2013; 61: 1999-2005.

35. Virketis D. Bičių surinktų šviežių žiedadulkių drėgnumas. Lietuvos bitininkas, 1993; 5: 22-4. Lithuanian.

36. Xue X, Jonathan NS, Liuwei Z, Haimin D, Fengmao L, Yang L, Yi L. Simultaneous determination of aflatoxins and ochratoxin $\mathrm{a}$ in bee pollen by low-temperature fat precipitation and immunoaffinity column cleanup coupled with LC-MS/MS. Food Anal Methods. 2014; 7(3): 690-96.

\section{Jolanta Sinkevičienè, Algirdas Amšiejus MIKROSKOPINIŲ GRYBŲ PAPLITIMAS BIČIŲ SURINKTOSE ŽIEDADULKĖSE}

\section{Santrauka}

Viena iš bičių produktų, žiedadulkių, sandèliavimo problemų - jų mikrobiologinė tarša. Esant didelei mikroskopinių grybų taršai žiedadulkèse, kai kurių genčių grybų sintetinami toksinai gali turèti neigiamos įtakos vartotojų sveikatai. Eksperimento metu buvo įvertintas mikroskopinių grybų paplitimas bičių žiedadulkèse bei nustatyta grybų gentinė ir rūšinè sudètis. Ištirti 46 bičių žiedadulkių mėginiai, surinkti skirtingu sezono laiku (pavasarị ir vasarą). Siekiant nustatyti mėginyje esančius grybų pradus bei jų kieki, naudotas skiedimo metodas (KSV/g). Bendras mikromicetų pradų skaičius pavasarinėse žiedadulkèse svyravo nuo 1,3 iki 5,7 × $10^{-3} \mathrm{KSV} / \mathrm{g}$, vasarinèse - nuo $1,0 \mathrm{iki} 5,8 \times 10^{-3} \mathrm{KSV} / \mathrm{g}$. Tyrimų metu žiedadulkèse buvo nustatyti 11 genčių ir 6 rūšims priklausantys grybai. Pavasarị ir vasarą rinktų žiedadulkių genčių ir rūšių skaičius mažai skyrèsi. Pavasarị surinktose žiedadulkèse buvo išskirta 10 genčių ir 6 rūšims priklausantys grybai, vasarą - 11 genčių, tarp jų identifikuotos 6 rūšys. Žiedadulkèse vyravo Penicillium ir Alternaria spp. grybai.

Raktažodžiai: bičių žiedadulkès, grybai, tarša 